\title{
Brief Introduction on the Legal Fiduciary Relationship Quanyi $\mathrm{Li}^{1, \mathrm{a}}$, Tiantian Guo ${ }^{2, \mathrm{~b}}$, Siming, Zhang ${ }^{3, \mathrm{c}}$ \\ ${ }^{1}$ Capital University of Economics, China \\ ${ }^{2}$ Capital University of Economics, China \\ ${ }^{3}$ Capital University of Economics, China \\ a1335083020@qq.com,b424320342@qq.com,c769497917@qq.com
}

\section{Keywords: Fiduciary relationship, morality}

\begin{abstract}
Both oriental civilization and western civilization pay more attention to the fiduciary role in the social development. The fiduciary relationship has been considered as the foundation in Chinese society. "Where there is no credit, there is no foothold". During the Athens period of the western society, fiduciary was also the foundation to establish a city-state country. In modern times, the role of the fiduciary relationship in the society mainly came from the religion. In contemporary age, the fiduciary with the function of religion has had the fewer and fewer social influences, but the application of the fiduciary relationship is gradually shown in the law, showing that the social development can't be separated from the fiduciary. In this paper, the author summarized the fiduciary application in Chinese legal relationship. The fiduciary relationship actually belongs to a kind of morality, which has uncertainty, thus the legal relationship about the fiduciary can't be completely enumerated. In the fiduciary relationship, the host law is required to guide the legal fiduciary relationship. In this paper, the author extracted the legal fiduciary relationship part to briefly elaborate.
\end{abstract}

\section{Introduction}

The fiduciary is the foundation of people to people communication and also lays a foundation on social economic activities and political activities. It plays an important role in the human society. In the existing system design, the natural properties of mankind and substance desire are used as the foundation, but the conventional role of morality in the society is neglected. If there is no specific mechanism for the constraint management, social development will be out of control ${ }^{1}$. "Where there is no credit, there is no foothold; where there is no credit, there is no success; where there is no credit, there is no prosperity". "Credit" has had the higher status during the Spring and Autumn period. It is the foundation of social management and national foundation ${ }^{2}$. In the establishing process of the western society, "fiduciary" also has a great role on stabilizing the society. In the modern legal relationship, the trusteeship, agency system and contract system are established on the basis of legal fiduciary relationship. ${ }^{3}$ With the development and interpenetration of the civil law system and Anglo-American law system, the fiduciary relationship is widely applied in the civil law countries and it is scattered in each partial law of China. However, there is no systemization or systematic cognition in practice.

\footnotetext{
${ }^{1}$ Rolls, theory of justice, translated by H. H. He, China Social Sciences Press, pp.4, 1988.

2 The Analects. Yan Yuan: Zigong asked Confucius to how to govern. And Confucius answered, "if people have sufficient grains and national defense line has the sufficient military forces, people will trust you. If you can be trusted by people, there is no doubt that the country is prosperous and the people are at peace." Zigong asked again, "If it is necessary to remove a condition, which one shall be firstly removed among three of them?" Confucius answered, "Military forces". Zigong asked again, "If it is necessary to remove a condition, which one shall be removed between the remaining ones?" "Grains, because where there is no credit, there is no foothold."

${ }^{3}$ C. S. Peng, the analysis and application of legal fiduciary relationship [J], Human Social Sciences, vol.(3), pp.206-208, 2010.
} 


\section{Theoretical Foundation of the Fiduciary Relationship}

Fiduciary was originated from the Roman law. It is a derivative word of fides or bona fides ${ }^{4}$, which was originated from fiduciary, fiduciary duty and fiduciary relationship in the Anglo-American law system, showing the meaning of trust and credit. It means that the beneficiaries give the maximal trust to trustees, thus trustees will handle affairs for beneficiaries with the sincere and selfless attitude and maximal goodwill. Fundamentally, fiduciary is a kind of moral requirement in people to people communication. In the social development process of China and the west, it hopes that the social development can be based on morality of mankind for many times. For example, in traditional Chinese culture, Laozi advocated following up with the natural step, while Confucius emphasized that "the authority shall have virtues" and "the authority shall overcome people with virtues". In the Bible, it shows that "But the fruit of the Spirit is love, joy, peace, longsuffering, gentleness, goodness, faith. Meekness, temperance: against such there is no law." (Galatians, 5:22-23). However, the greatest difficulty of regarding morality as the foundation of the social development is that morality has uncertainty, thus adaptability in tactics of morality is required-“justice".

Fiduciary relationship means that beneficiaries give the sufficient trust and trust to trustees, thus trustees cherish the greatest goodwill and use sincere and selfless attitude to deal with beneficiaries. It means that interests of other people are prior to the own interests. Trustees will handle affairs as the interests of beneficiaries. This is the largest feature of legal fiduciary relation, showing the meanings in these aspects: first of all, trustees handle affairs on behalf of beneficiaries. Both of them have the agency or representative relation. Next, the reason why trustees can handle affairs for beneficiaries is that they gain the authorization from beneficiaries, so as to focus on the interests of beneficiaries. Such authorization can be determined or statutory. The core of fiduciary relationship lies in conforming to the obligations of fidelity and interest behaviors of beneficiaries when trustees handle affairs for beneficiaries. Fiduciary is an important part in morality and has uncertainty, showing that the law shall consider the circumstances that trustees can't fulfill obligations of fidelity at the fixed time, including two aspects. First of all, the vested interests are abused. Secondly, they are responsible for agency out of the right range.

\section{The Important Role and Practical Puzzle of Fiduciary in Today's Society}

The law is used for standardizing the social order and plays a role of stopping disputes. It is established on the relatively uniform value. Since the ancient times, "fiduciary" is the foundation of the universal cognition in both the eastern society and western society. In the western society, the Bible describes the source of mankind. Meanwhile, the reason why Adam and Eve were driven out of the Garden of Eden was that Adam and Eve violated the appointment with the God and they ate the forbidden fruit, thus they were driven out of the Garden of Eden. The primary cause that mankind has suffering is because Adam and Eve were short of "fiduciary" at the very starting. Some people also think that the Bible is the contract between the God and mankind. People who abide by the contract will go to the heaven after death, while people who "violate the contract" will go to the hell after death. Similarly, the social stabilization of "fiduciary" in traditional Chinese culture is also presented in various aspects. For example, the old sayings that "no one picks up and pockets anything lost on the road, as well as doors are unbolted at night" yearned by the mankind. Confucius wrote in the Analects, "If someone breaks his promise, how can he conduct himself in society. It seems that oxcart and carriage have no wheels, and how can they drive forward?" Therefore, it can be observed that the social development can't be separated from "fiduciary".

\footnotetext{
${ }^{4}$ H. D. Wu, on the right of credit, the Law, vol.(1), pp.35, 2001.

5 Hanfeizi Waichushuo Zuoshang, "there are no robbers in the country and no one picks up and pockets anything lost on the road".
} 
However, when the society is based on the "fiduciary", people will meet with an inevitable problem-uncertainty of morality. Confucius discussed uncertainty of morality in the Analects, "Without school rites, integrity is easy to be used by other people, so as to bite off one's own head". That is to say, if there is certain principle and flexibility as abiding by the "fiduciary" process, it may "just be the opposite to what you wish" by abiding by "fiduciary", because there are some mutually overlapping moral conflicts. For example, the moral principle can't be abided at certain moment. Mengzi mentioned "It is improper for men and women to touch each other's hand in passing objects. However, if the sister-in-law falls into water, whether you will save or not?"7 If other people have a fight, whether we shall pay attention to our own moral uplift without thought of others or take up the cudgels against an injustice. ${ }^{8}$ When enemies invade, will you risk your life to save the master or protect yourselves by running away ${ }^{9}$ This requires people to flexibly master the moral standards. They not only shall abide by "fiduciary" principles in life, but also shall abide by "fiduciary" in fluctuation. The so-called "fiduciary" means integrity and authenticity. Such "fiduciary" not only includes externality, but also contains internality. At the same time, on the basis of abiding by "fiduciary", it is necessary to master the "meaning" in flexibility. The "meaning" stands for mastering "fiduciary" flexibility. Meanwhile, it also contains the final results and purposes contained in "fiduciary"-_ "justice." Only to combine them together can it really achieve the goal required by abiding by "fiduciary." It not only is the compass of conduct between people, but also is the foundation of social political system - the closeness of meanings.

\section{Application of the Fiduciary Relationship in Law}

Fiduciary plays the important role in social development and social order construction, thus it is extremely important to bring fiduciary into the national governance. Before the modern times, the Bible has the status and potency prior to the natural law and secular law in the society. The legalization of fiduciary is embodied by religion and morality, so as to generate a direct influence on the social system and social order. Since the modern society, social structure has been greatly changed. The social influences of religion are reflected in culture and religious belief. Also, legal influences disappeared. Nevertheless, social development and management can't be separated from the fiduciary foundation, thus fiduciary legalization has the important legal significance.

\footnotetext{
6 The Analects. Yanghuo, the original: Confucius said, "You, Have you heard of six virtues and six drawbacks?" Ziyou answered, "No". Confucius said, "Sit down, I will tell you. If you have the kindheartedness, but don't study well, you will be fooled by people; if you have the smart, but don't study well, you will dissolute; if you have the integrity, but don't study well, you will do harms to loved ones; if you have straightforwardness, but don't study well, you will have a sharp tongue; if you have courageousness, but don't study well, you will defy your superiors and start a rebellion; if you have rigidness, but don't study well, you will be arrogant."

7 Mengzi Lilou Volume One, Chunyu Kun said, "It is right that it is improper for men and women to touch each other's hand in passing objects?" Mengzi said, "Right." Chunyu Kun said again, " if the sister-in-law falls into water, whether you will save or not?" Mengzi said, "If not, you are jackals and wolves. However, it is a social rite that it is improper for men and women to touch each other's hand in passing objects; if so, it means flexibility."

8 Mengzi Lilou Volume Two, If people on their own side have a fight, you will save them, even if you have hair dishevelled and sloppily dressed. If other people have a fight, it is difficult for you to save them with hair dishevelled and sloppily dressed. It means that relatives and other people have emotional differences. It doesn't mean that Mengzi agrees with such an opinion, but it exactly has had such a phenomenon at that time.

9 Mengzi Lilou Volume Two, Zengzi lived in Wucheng. A Yue bandit came. Someone said, "a Yue bandit is coming, so why don't you just leave?" Zengzi said, "Don't let people live here and don't let them destroy those forests." After a Yue bandit left, Zengzi said, "To repair my wall. I am going to come back." After a Yue bandit left here, Zengzi returned to Wucheng. Someone asked him, "Officials in Wucheng was respectful to you. When the Yue bandit came, you left in advance and became a model for the public. However, after the Yue bandit left, you just returned. This might be unsuitable." Shen Youxing said, "You may not understand this principle. I once met with Fu Chu. At that time, 70 people followed up with Zengzi and no one joined the rebellion." When Zisi lived in the state of Wei, a Qi bandit invaded. Someone said, “a Qi bandit is coming, so why don't you just leave.” Zisi said, "If so, who will guard the city with wei?" Mengzi said, "Zengzi and Zisi have had the same proposal. Zengzi was a teacher at that time and superior like a father or a brother. Zisi was a small official. If Zengzi changed the position with Zengzi, they will make the same choice."
} 
Fiduciary relationship is mainly reflected in both parties with the trust relationship. The one party resigns his rights to other people based on the trust relationship. The other party handles affairs entrusted by the principal on the basis of loyal obligations, so as to form a legal relationship to fulfill obligations for principal. Such a mode is frequently used in the modern law.

(1) Agency by agreement: agency by agreement means that the attorneyship of the agent is generated in line with the authorization of the principal. Such authorization includes determination and statutory. In the agency by agreement, the principal refers to the principal, while the agent is the trustee. In this relationship, "fiduciary" is the moral foundation to establish such a legal relationship. Without fiduciary, such agency may constitute the other legal relationship. For example, under the unknown situation, parties involved may form the spontaneous agency. If the trustee fails to fulfill loyal obligations and has the right to deal with trust with malignity, serious problems will be caused. Under the circumstance, the other features of the agency by agreement with the "fiduciary" property will display the value. First of all, in the legal relationship of agency by agreement, ownership of the principal is separated from the control management power of trustee. Secondly, in the legal relationship of rights and obligations, the broad authorization or responsibility is applied. The law provides the following solutions for the interest conflict between the principal and trustee: (1) If the trustee exceeds the agent range or hides the material fact from the principal, such an act will be invalid in validity to be determined of the civil law. (2) If both parties have a dispute in the disclosure of some material fact, the trustee shall assume the burden of proof to disclose the material fact to the principal. (3) If obligations of the principal are damaged, because of the trustee's malicious act or behaviors that don't conform to the loyal obligations, the principal can propose compensations for damaged properties to the trustee. These three factors interact in the agency by agreement to protect the legal relationship of the trust-based agency by agreement can be conducted normally and prevent from unsolved situation, because of abusing the reliance interests of the principle. This means to use the fiduciary relationship to solve some realistic and legal problems, so as to provide convenience for the principal by trust. Then, "fiduciary" can protect the reliance interests in the legal relationship of the agency by agreement.

(2) Contract and corporate management: Legal fiduciary relationship also has certain application. In the contract relationship, there are some differences between the contract relationship and fiduciary relationship in the properties. However, the status of the trustee and the principal in the fiduciary may not the same. The trustee can more conveniently contact with the properties or other interests of the principal. The principal's interests shall be guaranteed. In the contract relationship, parties involved in a contract have the equal status. Both parties will handle affairs respectively for their own interests. ${ }^{10}$ Actually, it doesn't mean that the fiduciary relationship is completely irrelevant of the contract relationship. In some aspects, the contract signature is based on the fiduciary relationship, e.g. disclosure of some business secrets. In addition, the contract also belongs to the fiduciary relationship and it is the increase of the fiduciary relationship in the legal level.

(3) Corporate system: the fiduciary relationship also has certain application in this aspect. Both of them have some differences to some extent. As a modern corporate system, corporate system is partial to the corporate control and management, while the fiduciary relationship pays more attention to using the fiduciary relationship to restrain act of trustees. In fact, the fiduciary relationship is still the foundation of the corporate governance mode. In the corporate governance, the fiduciary relationship is firstly embodied in the separation of ownership and managerial authority of the company. Moreover, the corporate owners have the broad authorization for corporate managers. Corporate managers depend on loyal obligations to fulfill responsibilities for the company, which conforms to the features of the fiduciary relationship. In addition, in the status of owners and managers in the corporate governance, due to the separation of owners and controllers in the operation interests, the party controlling interests have the possibility to embezzle interests, so as to damage the interests of beneficiaries. In this possibility and fiduciary relationship,

10 S. B. Ni and Y. R. Zhang, the Study on Fiduciary Duties in the Securities Investment Consulting Institutions[J], Social Science, vol.(10), pp.103-112, 2014. 
it has the same situation with the abuse of "fiduciary". Though the articles of association and contracts will have stipulations on this aspect and corporate law also has the relevant stipulations, there are all kinds of problems in the corporate operation process. Moreover, with the rapid economic development, it is impossible to meet corporate management demands just by relying on the detailed legal articles or articles of association. Based on it, it can draw a conclusion the corporate governance mode is similar to the operation mode of the fiduciary relationship. It is extremely necessary to pressure the managers in the fiduciary relationship, so as to safeguard the interests of corporate owners.

\section{Legalization of the Fiduciary Relationship}

The fiduciary relationship in the law can be reflected in the multiple legal environments, including the agency by agreement, contract relation and corporate management process. Actually, there are lots of complicated legal relations and rules in the realistic life. In the fiduciary relationship, fiduciary is a kind of moral dependence and it is impossible to enumerate all profit-making acts by using such a trust relationship. According to the existing law in China, problems based on these legal relationships will be solved by different departmental laws or regulations. As a matter of fact, if these legal relations have certain similarity, more time and judicial costs will be saved by using the uniform host law. Meanwhile, it can be more suitable for more cases and keep pace with the era. The generality of the fiduciary relationship can be extracted from the trust, agency, corporate governance and contract. The applicable range of the fiduciary relationship and circumstance of abusing the principal's trust are summarized to form the uniform concept of the host law. To establish the fiduciary relationship law is good for restraining the trustee and agent or even directors effectively. Meantime, the fiduciary relationship is equipped with the profound morality to compensate for the serious moral deficiency in the current legal environment.

To begin with, it is necessary to define the contents and applicable range of the fiduciary relationship. The fiduciary relationship has certain difference in legal contents and moral meanings. The fiduciary relationship shall be suitable for the precondition that the principal gives the broad authorization to the trustee. When the trustee deals with the rights or interests of the principal, he will conduct the effective control or management on the principal's properties or rights, showing the following features: 1. In the fiduciary relationship, the operational control right and management right of the object controlled or managed by the principal are separated; 2 . When the trustee controls or manages the object, it has the possibility to fulfill obligations with malignity, so that damage will be caused to the principal and rights.

Secondly, it is necessary to define the subjects of the legal fiduciary relationship and obligations. According to the contents and applicable range of the fiduciary relationship, fiduciary relationship mainly has two parties. One party gives trust and gives the own control right to the other party for disposal. The other party is the trustee that controls and manages the rights of the principal. In the fiduciary relationship, the principal places their rights under the control of the other party. In order to safeguard the rights of the principal, the trustee's obligations in the legal fiduciary relationship shall be the main contents. Firstly, the trustee shall abide by the loyal obligations and handle affairs for the maximum interests for the principal, including (1) it is necessary to conduct the reasonable information disclosure. In the material decision or material variation, the principal shall be informed. (2) The trustee can't use their posts to seek profits for themselves. (3) The trustee shall rationally fulfill their obligations and can't relegate their obligations to the third party. (4) The trustee shall deal with the principal's rights in the appointed rational range with the principal. (5) In the disposal of the professional items, the trustee shall have the corresponding professional ability or qualification certificate and tell the truth to the principal. Furthermore, the principal shall assume the obligations to give salary to the trustee and provide certain assistance and convenience for the trustee. If there is any dispute, due to the convenience in contacting with the principal's rights, the trustee shall assume the greater burden of proof.

Thirdly, it is necessary to define the value orientation to solve the legal fiduciary relationship. Differing form the contract relationship, the legal fiduciary relationship may not protect the interests 
of the contract parties. Instead, it pays more attention to protecting the interests of the principal. In the fiduciary relationship, the principal gives trust and control right of their own rights. At the moment of establishing the fiduciary relationship between both parties, the interests of the principal is kept in the relatively unstable state. The interest safeguard of the principal depends on the fulfillment of the trustee's loyal obligations. As a result, it is necessary to value the interest protection of the principal.

\section{References}

[1] C. S. Peng, the analysis and application of legal fiduciary relation[J], Human Social Sciences, vol.(3), pp.206-208, 2010.

[2] Y. D. Zou, the discussion on the information disclosure system of the securities investment funds[D], Jilin University, 2007

[3] S. B. Ni and Y. R. Zhang, the Study on Fiduciary Duties in the Securities Investment Consulting Institutions[J], Social Science, vol.(10), pp.103-112, 2014.

[4] P. Chen, the integrity evaluation and integrity society [J], Journal of Hunan Institute of Technology, vol.(6), pp.63-66, 2007.

[5] $\mathrm{L} . \mathrm{Xu}$, the conflict and balance discussion on the beneficiaries and the third party in the trusteeship[D], Southwest University of Political Science and Law, 2006.

[6] Y. L. Liu, the legislative defects and realistic operation problems in the internal supervision mechanism of Chinese listed companies[J], Journal of Guizhou Nationalities University(Philosophy and Social Science Version), vol.(6), pp.62-64, 2004. 